ISSN: $1412-8837$

\title{
KAJIAN KETAHANAN PANGAN DAN KERAWANAN PANGAN DI PROVINSI BENGKULU
}

\author{
Assessment of Food Security and Food Insecurity in Bengkulu Province \\ Gita Mulyasari \\ Jurusan Sosial Ekonomi Pertanian Fakultas Pertanian Universitas Bengkulu \\ gita_mulyasari@yahoo.co.id
}

\begin{abstract}
Bengkulu Province develop FSVA which is a very significant tool in planning and decision making to reduce the gap of food security in Bengkulu Province. This research was conducted in Bengkulu Province using descriptive methods. The data used is secondary data collected from literature relating to food security and food insecurity in Bengkulu Province. FSVA can detect food security and food insecurity conditions is based on 9 indicators, a) normative consumption ratio, b) The percentage of population under the poverty line, c) the number of villages with no public transportation access, $d$ ) the percentage of households without electricity access, e) life expectation, f) illiterated women, g) under height toddlers, $h$ ) households without clean water access, and the last i) the percentage households far from healthy access.
\end{abstract}

Key words: food security, food insecurity, Vulnerability

\section{PENDAHULUAN}

Indonesia yang memiliki penduduk 230 juta dengan beraneka ragam budaya, sosio-ekonomi dan letak geografis menduduki peringkat 107 dari 177 negara untuk Indeks Pembangunan Manusia (Human Development Index tahun 2008). Meskipun Indonesia mengalami pemulihan yang cukup berarti sejak krisis ekonomi tahun 1998, namun masalah kemiskinan, kerawanan pangan dan gizi masih cukup besar dan beragam antar provinsi dan kabupaten. Indonesia sebagai salah satu negara yang ikut menandatangani World Food Summit (1996) dan Millennium Declaration (2000), terus menerus memperkuat upayanya untuk mencapai tujuan pertama dari Millennium Development Goals (MDG), yaitu menurunkan proporsi penduduk yang tingkat pendapatannya di bawah US\$ 1 per hari dan proporsi penduduk yang menderita kelaparan menjadi setengahnya pada tahun 2015.

Ketahanan pangan atau food security mencakup banyak aspek sehingga setiap orang mencoba menterjemahkan sesuai dengan tujuan dan ketersediaan data serta diinterpretasikan dengan banyak cara. International Congres of 
Nutrition (ICN) yang diselenggarakan di Roma tahun 1992 mendefinisikan ketahanan pangan sebagai kemampuan rumah tangga untuk memenuhi kecukupan pangan anggotanya dari waktu ke waktu agar dapat hidup sehat dan mampu melakukan kegiatan sehari-hari. Sidang Committee on World Food Security 1995 memperluas definisi dengan menambah persyaratan "harus diterima oleh budaya setempat" (Rachman \& Ariani, 2002). Definisi tersebut dipertegas lagi pada Deklarasi Roma tentang Ketahanan Pangan Dunia dan Rencana Tindak Lanjut Konferensi Tingkat Tinggi (KTT) Pangan Dunia tahun 1996 menjadi situasi dimana semua rumah tangga pada setiap saat memliki akses (baik fisik maupun ekonomi) untuk memperoleh pangan yang cukup, aman dan sehat bagi seluruh anggota rumah tangganya. Definisi tersebut merupakan definisi oleh Food Agriculture Organization (FAO) yang telah diterima secara luas di tingkat internasional. Lebih lanjut, World Food Summit (1996) mendefinisikan ketahanan pangan sebagai "Ketahanan pangan terjadi apabila semua orang secara terus menerus, baik secara fisik, sosial, dan ekonomi mempunyai akses untuk pangan yang memadai/cukup, bergizi dan aman, yang memenuhi kebutuhan pangan mereka dan pilihan makanan untuk hidup secara aktif dan sehat" FSVA dibuat berdasarkan tiga pilar ketahanan pangan: (i) ketersediaan; (ii) akses; dan (iii) pemanfaatan pangan.

Menurunkan tingkat kemiskinan, kerawanan pangan dan kesenjangan antar wilayah tetap merupakan tantangan yang besar bagi pihak perencana dan pengambil kebijakan. Luasnya wilayah, keanekaragaman budaya dan terkonsentrasinya penduduk miskin di daerah tertentu merupakan hambatan untuk menentukan tingkat kerawanan pangan mereka. Selain itu, pembentukan sejumlah kabupaten baru dalam 3 tahun terakhir menyebabkan perlunya analisis dan pemetaan ketahanan pangan yang lebih mutakhir. Oleh karena itu, FIA yang pertama perlu dimuktahirkan untuk menggambarkan perkembangan situasi ketahanan pangan terkini.

Pada tahun 2010, Provinsi Bengkulu mulai mengembangkan FSVA (Food security and vulnerability atlas). FSVA ini akan menjadi alat yang sangat penting dalam perencanaan dan pengambilan keputusan untuk mengurangi kesenjangan ketahanan pangan yang merupakan tantangan besar,dari semua kabupaten ,kecamatan yang ada di Provinsi Bengkulu akan diikut sertakan, terkecuali kota Bengkulu tidak diikut sertakan sebab ketahanan pangan perkotaan perlu dianalisis secara terpisah yang mungkin akan menjadi pertimbangan di masa depan. Tidak hanya itu FSVA ini bertujuan untuk mengetahui berbagai penyebab kerawanan pangan secara lebih baik atau dengan kata lain kerentanan terhadap kerawanan pangan, bukan hanya kerawanan pangan itu sendiri. Dari latar belakang di atas maka tujuan dari penelitian ini adalah mengkaji ketahanan pangan dan kerawanan pangan di Provinsi Bengkulu dengan melalui pendekatan FSVA (Food security and vulnerability atlas). 


\section{METODE PENELITIAN}

Metode yang digunakan dalam penelitian ini adalah metode deskriptif. Menurut Nazir (1999) metode deksriptif adalah merupakan suatu metode dalam meneliti suatu objek, suatu set kondisi, suatu sistem pemikiran ataupun suatu kelas peristiwa dengan tujuan untuk membuat deskripsi, gambaran secara sistematis, factual dan akurat mengenai fakta-fakta, sifat-sifat serta hubungan antar fenomena yang diselidiki. Dengan menggunakan metode ini memungkinkan untuk mendapatkan informasi yang lebih detail mengenai keadaan selama ini.

Data yang digunakan dalam penelitian ini merupakan data sekunder yaitu data yang diperoleh melalui literatur yang berkaitan dengan bagaimana situasi dan kondisi ketahanan pangan dan kerawanan pangan di Provinsi Bengkulu. Data-data yang diperlukan berupa Data Untuk Pemetaan Ketahanan dan Kerentanaan Pangan (FSVA), Data Produksi Pangan Lokal di Provinsi Bengkulu, Data Rumah Tangga atau Masyarakat yang telah diestimasi dari BPS.

\section{HASIL DAN PEMBAHASAN}

\section{Peta Ketahanan dan kerentanan Pangan}

Peta ketahanan dan kerentanan pangan merupakan suatu instrumen untuk memotret situasi pangan di suatu wilayah. Peta ketahanan dan kerentanan pangan disusun berdasarkan beberapa indikator yang sudah ditetapkan oleh World Food Programme. Indikator-indikator tersebut dikelompokan ke dalam 3 dimensi (i) ketersediaan pangan (food availability), (ii) akses pangan dan mata pencaharian (food and livelihoods acsess), dan (iii) kerawanan pangan sementara (transient food insecurity). Tujuan pembuatan peta ketahanan dan kerentanan pangan (FSVA) adalah: (i) menyoroti kondisi ketahanan dan kerentanan terhadap pangan pangan tingkat kabupaten di Indonesia berdasarkan indikator terpilih, (ii) mengidentifikasi penyebab kondisi ketahanan dan kerentanan pangan di kabupaten, dan (iii) menyediakan petunjuk dalam mengembangkan strategi mitigasi yang tepat untuk kerentanan pangan kronis. Kegiatan FSVA menggunakan 13 (tiga belas) indikator, terbagi ke dalam dua klasifikasi, yaitu indikator kronis dan transien. Pemetaan di tingkat nasional hanya menggunakan 10 indikator yang meliputi aspek ketersediaan, aspek akses pangan dan mata pencaharian dan aspek pemanfaatan pangan. Sedangkan untuk tingkat provinsi menggunakan ke 13 indikator tersebut dimana terdiri dari 9 indikator untuk pemetaan pada wilayah ketahanan dan kerentanan pangan kronis dan 4 indikator (aspek kerentanan) untuk pemetaan rawan pangan transien. Peta ketahanan dan kerentanan pangan komposit dibuat dengan menghitung indeks komposit ketahanan dan kerentanan pangan dengan cara menggabung seluruh indikator dan 
memberikan bobot pada indikator dengan menggunakan metode Principal Component Analysis. Peta komposit menunjukkan kondisi ketahanan dan kerentanan pangan berdasarkan gabungan berbagai dimensi ketahanan dan kerentanan pangan. Penyebab kondisi ketahanan dan kerentanan pangan dapat diketahui dengan mempelajari kondisi per indikator.

\section{Tabel 1. Indikator dan Definisinya pada Peta Ketahanan dan Kerentanan Pangan (FSVA)}

\begin{tabular}{|c|c|c|c|c|}
\hline Judul & Indikator & Definisi & $\begin{array}{c}\text { Sumber } \\
\text { Data }\end{array}$ & Keterangan \\
\hline 1. \% kemiskinan & $\begin{array}{l}\text { Persentase } \\
\text { penduduk hidup } \\
\text { di bawah garis } \\
\text { kemiskinan }\end{array}$ & $\begin{array}{l}\text { Nilai rupiah pengeluaran per } \\
\text { kapita per bulan untuk } \\
\text { memenuhi standar minimum } \\
\text { kebutuhan konsumsi pangan dan } \\
\text { non pangan yang dibutuhkan } \\
\text { oleh seorang individu untuk } \\
\text { hidup secara layak }\end{array}$ & $\begin{array}{l}\text { SUSENAS } \\
2013 \text { dan } \\
\text { Sensus } \\
\text { Penduduk } \\
2010\end{array}$ & $\begin{array}{l}\text { Diolah dengan } \\
\text { SAE (Small } \\
\text { Area } \\
\text { Estimation) }\end{array}$ \\
\hline 2. \% Listrik & $\begin{array}{l}\text { Persentase } \\
\text { rumah tangga } \\
\text { tanpa akses } \\
\text { listrik }\end{array}$ & $\begin{array}{l}\text { Persentase rumah tangga yang } \\
\text { tidak memiliki akses terhadap } \\
\text { listrik dari PLN dan/atau non } \\
\text { PLN, misalnya generator }\end{array}$ & $\begin{array}{l}\text { SUSENAS } \\
2013 \text { dan } \\
\text { Sensus } \\
\text { Penduduk } \\
2010 \\
\end{array}$ & $\begin{array}{l}\text { Diolah dengan } \\
\text { SAE (Small } \\
\text { Area } \\
\text { Estimation) }\end{array}$ \\
\hline 3. \% Air Bersih & $\begin{array}{l}\text { Persentase } \\
\text { rumah tangga } \\
\text { tanpa akses ke } \\
\text { air bersih }\end{array}$ & $\begin{array}{l}\text { Persentase rumah tangga yang } \\
\text { tidak memiliki akses ke air } \\
\text { minum yang berasal dari ledeng } \\
\text { meteran, ledeng eceran, sumur } \\
\text { bor/pompa, sumur terlindung, } \\
\text { mata air terlindung, dan air } \\
\text { hujan dengan memperhatikan } \\
\text { jarak ke jamban minimal } 10 \mathrm{~m}\end{array}$ & $\begin{array}{l}\text { SUSENAS } \\
2013 \text { dan } \\
\text { Sensus } \\
\text { Penduduk } \\
2010\end{array}$ & $\begin{array}{l}\text { Diolah dengan } \\
\text { SAE (Small } \\
\text { Area } \\
\text { Estimation) }\end{array}$ \\
\hline 4. \% Buta huruf & $\begin{array}{l}\text { Persentase } \\
\text { perempuan buta } \\
\text { huruf }\end{array}$ & $\begin{array}{l}\text { Persentase perempuan di atas } 15 \\
\text { tahun yang tidak dapat membaca } \\
\text { atau menulis huruf latin }\end{array}$ & $\begin{array}{l}\text { SUSENAS } \\
2013 \text { \& } \\
\text { Sensus } \\
\text { Penduduk } \\
2010 \\
\end{array}$ & $\begin{array}{l}\text { Diolah dengan } \\
\text { SAE (Small } \\
\text { Area } \\
\text { Estimation) }\end{array}$ \\
\hline 5. \% Stunting & $\begin{array}{l}\text { Persentase balita } \\
\text { tinggi kurang } \\
\text { (stunting) }\end{array}$ & $\begin{array}{l}\text { Anak di bawah lima tahun yang } \\
\text { tinggi badannya kurang dari } 2 \\
\text { Standar Deviasi (2-SD) dengan } \\
\text { indeks tinggi badan menurut } \\
\text { umur (TB/U) }\end{array}$ & $\begin{array}{l}\text { SUSENAS } \\
2013 \& \\
\text { Sensus } \\
\text { Penduduk } \\
2010 \\
\end{array}$ & $\begin{array}{l}\text { Diolah dengan } \\
\text { SAE (Small } \\
\text { Area } \\
\text { Estimation) }\end{array}$ \\
\hline $\begin{array}{l}\text { 6. Angka } \\
\text { Harapan Hidup }\end{array}$ & $\begin{array}{l}\text { Angka harapan } \\
\text { hidup pada saat } \\
\text { lahir }\end{array}$ & $\begin{array}{l}\text { Perkiraan lama hidup rata-rata } \\
\text { bayi baru lahir dengan asumsi } \\
\text { tidak ada perubahan pola } \\
\text { mortalitas sepanjang hidupnya }\end{array}$ & $\begin{array}{l}\text { SUSENAS } \\
2013 \text { \& } \\
\text { Sensus } \\
\text { Penddk } 2010 \\
\end{array}$ & $\begin{array}{l}\text { Diolah dengan } \\
\text { SAE (Small } \\
\text { Area } \\
\text { Estimation) } \\
\end{array}$ \\
\hline $\begin{array}{l}\text { 7. } \% \\
\text { Transportasi }\end{array}$ & $\begin{array}{l}\% \text { desa yang tidak } \\
\text { memiliki akses } \\
\text { penghubung yang } \\
\text { memadai }\end{array}$ & $\begin{array}{l}\text { Persentase desa yang tidak } \\
\text { memiliki akses penghubung } \\
\text { yang dapat dilalui kendaraan } \\
\text { roda } 4 / \text { lebih atau sarana } \\
\text { transportasi air }\end{array}$ & $\begin{array}{l}\text { PODES } \\
2011, \text { BPS }\end{array}$ & $\begin{array}{l}\text { Data mentah } \\
\text { PODES } 2011 \\
\text { karena PODES } \\
2014 \text { diluncur } \\
\text { kan } 2015 \\
\end{array}$ \\
\hline $\begin{array}{l}\text { 8. Akses } \\
\text { Kesehatan }\end{array}$ & $\begin{array}{l}\text { \% keluarga yang } \\
\text { tinggal di desa } \\
\text { dengan jarak lebih } \\
\text { dari } 5 \mathrm{~km} \text { dari } \\
\text { fasilitas kesehatan } \\
\end{array}$ & $\begin{array}{l}\text { Persentase keluarga yang } \\
\text { tinggal di desa dengan jarak } \\
\text { lebih dari } 5 \mathrm{~km} \text { dari fasilitas } \\
\text { kesehatan }\end{array}$ & $\begin{array}{l}\text { PODES } \\
\text { 2011, BPS }\end{array}$ & $\begin{array}{l}\text { Data mentah } \\
\text { PODES } 2011 \\
\text { karena PODES } \\
2014 \text { diluncur } \\
\text { kan } 2015 \\
\end{array}$ \\
\hline
\end{tabular}

Sumber: BKP Provinsi Bengkulu, 2015

86 | Gita Mulyasari, Kajian Ketahan Pangan dan Kerawanan Pangan ... 
Peta Ketahanan dan Kerentanan Pangan (FSVA) memuat peta yang ber informasikan daerah - daerah mana saja yang mengalami kerawanan pangan,dan juga untuk mengetahui berbagai penyebab kerawanan pangan secara lebih baik.Peta ketahanan dan Kerentanan Pangan dibuat berdasarkan 3 pilar, yaitu ketersediaan, akses dan pemanfaatan pangan. Untuk membuat peta ketahanan pangan data yang diambil yaitu data selama 3 tahun terakhir yaitu tahun 2011 s/d 2013.

\section{Indikator Peta Ketahanan dan Kerentanan Pangan Provinsi Bengkulu}

Dalam Penyusunan Peta Ketahanan Pangan harus memenuhi beberapa persyaratan data yang terbagi menjadi 3 Aspek yaitu data aspek ketersediaan pangan yang bersumberkan dari data produksi pangan pokok seperti padi, ubi kayu,ubi jalar dan jagung. Data aspek akses pangan yang bersumber dari persentase penduduk dibawah garis kemiskinan, Persentase desa yang tidak memiliki akses yang memadai dan persentase rumah tangga tanpa listrik. Data aspek pemanfaatan pangan yang bersumber dari data Persentase Desa yang tinggal lebih dari $5 \mathrm{~km}$ dari fasilitas kesehatan, Persentase Rumah Tangga tanpa akses ke air bersih, Perempuan Buta huruf, Berat badan balita di bawah standard dan Angka harapan hidup. Setelah data tersebut dikumpulkan maka data tersebut digabungkan kedalam aplikasi MAPINFOW yang telah ditentukan oleh Badan Ketahanan Pangan. Adapun penjelasan data dari 9 indikator tersebut adalah

\section{Aspek Ketersediaan Pangan}

Indikator yang digunakan adalah Rasio konsumsi normatif per kapita terhadap ketersediaan bersih serealia padi, jagung, umbi-umbian yang perhitungan ketersediaan bersih serealia per kapita per hari dihitung dengan membagi total ketersediaan serelia kecamatan dengan membagi populasinya (data penduduk pertengahan tahun 2012), konsumsi normatif serelia per hari/per kapita adalah 300 gr, kemudian didapat rasio konsumsi normatif jika rasio lebih besar dari 1 maka daerah defisit pangan dan daerah dngan rasio kurang dari 1 adalah surplus untuk produksi serealia, data tersebut bersumber dari BPS Kabupaten dalam angka 2011-2013.

\section{Aspek akses Pangan}

Indikator yang digunakan ada 3

a. Indikator persentase penduduk hidup di bawah garis kemisikinan di perhitungkan dengan melihat. Nilai rupiah pengeluaran per kapita setiap bulan untuk memenuhi standar minimum kebutuhan-kebutuhan konsumsi pangan dan non pangan yang dibutuhkan oleh seorang individu untuk hidup secara layak,data tersebut bersumber dari SUSENAS 2013 dan Sensus Penduduk 2010 yang telah diestimasi . 
b. Indikator persentase desa yang tidak memiliki akses penghubung yang memadai dilihat dari persentase desa yang tidak memiliki akses penghubung yang dapat dilalui kendaraan roda 4 /lebih atau sarana transportasi air , data tersebut bersumber dari PODES 2014, BPS (SAE)

c. Indikator persentase rumah tangga tanpa akses listrik dilihat dari presentase rumah tangga yang tidak memiliki akses listrik dari PLN dan /non PLN, misalnya generator, data bersumber dari SUSENAS 2013, dan Sensus Penduduk 2010 (SAE).

\section{Aspek Pemanfaatan Pangan}

Indikator yang digunakan ada 5:

a. Angka harapan hidup pada saat lahir diperhitungkan dari perkiraan lama hidup bayi baru lahir dengan asumsi tidak ada perubahan pola mortalitas sepanjang hidupnya data tersebut bersumber dari Sensus Penduduk 2010 (SAE).

b. Persentase balita tinggi kurang (stunting) dilihat dari anak di bawah lima tahun yang tinggi badannya kurang dari -2 standar deviasi (-2 SD) dengan indeks tinggi badan menurut umur (TB/U)

c. Persentase perempuan buta huruf dilihat dari persentase perempuan diatas 15 tahun yang tidak dapat membaca atau menulis huruf latin ,data bersumber dari SUSENAS 2013 dan Sensus Penduduk 2010 (SAE).

d. Persentase rumah tangga tanpa akses ke air bersih dilihat dari rumah tangga yang tidak memiliki akses air minum yang berasal dari ledeng meteran, ledeng eceran, sumur bor/pompa, sumur yang terlindung, mata air yang terlindung dengan memperhatikan jarak ke jamban minimal $10 \mathrm{~m}$ data bersumber dari SUSENAS 2013 dan Sensus Penduduk 2010 (SAE).

e. Persentase keluarga yang tinggal di desa dengan jarak lebih dari $5 \mathrm{~km}$ dari fasilitas kesehatan, data bersumber dari PODES 2014, BPS(SAE).

Setelah semua data 9 indikator tersebut diolah dan mendapatkan hasil maka data tersebut akan digabungkan dan diperhitungkan lagi dengan Metode Komposit. Metode Komposit adalah metode untuk menjelaskan situasi kerentanan pangan suatu wilayah berdasarkan kombinasi dan berbagai indikator / dimensi yang digunakan dalam penyusunan FSVA, dengan melihat hasil analisis komposit maka faktor-faktor yang mempengaruhi kondisi kerentanan suatu wilayah bisa diindetifikasikan. Tingkat kerentanan maupun faktor yang berpengaruh antar wilayah berebda-beda, sehingga perlu penyelesaian yang sesuai dengan kondisi wilayah masing-masing. 
ISSN: $1412-8837$

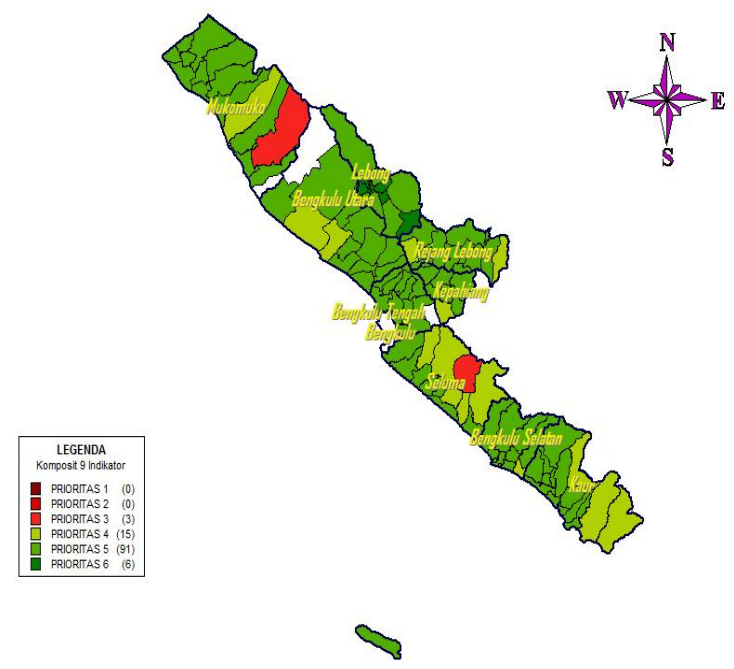

Gambar 1.

Peta Komposit 9 Indikator

Peta komposit menggambarkan prioritas dalam kelompok gradasi dengan pengelompokkan warna, yaitu merah tua (prioritas 1), merah (prioritas 2), dan merah muda (prioritas 3), kelompok warna merah tua menunjukkan kecamatan yang harus mendapatkan prioritas khusus dalam peningkatan ketahanan pangan dan penanganan masalah kerawanan pangan.pemetaan ini menggambarkan tingkat kemungkinan terjadinya kerawanan pangan suatu kecamatan secara relatif dibandingkan dengan kecamatan lainnya. Untuk warna hijau tua (Prioritas 6), hijau muda (Prioritas 5), hijau kekuningan (Prioritas 4), gradasi warna ini menunjukkan semakin tua maka daerah tersebut tahan pangan, tetapi tidak berarti semua yang hijau akan tahan pangan.

\section{SIMPULAN DAN SARAN}

\section{Simpulan}

Bahwa dengan adanya Peta Ketahanan dan Kerentanan Pangan (FSVA) Provinsi Bengkulu dapat menyoroti kondisi ketahanan dan kerentanan terhadap pangan tingkat kabupaten berdasarkan indikator terpilih, mengidentifikasi penyebab kondisi ketahanan dan kerentanan pangan di kabupaten, dan menyediakan petunjuk dalam mengembangkan strategi mitigasi yang tepat untuk kerentanan pangan kronis. Program pemetaan ini sangat menjanjikan dalam memberikan berbagai informasi yang pada akhirnya mengarah pada tujuan penurunan kemiskinan yang berkesinambungan.. 


\section{Saran}

Peta Ketahanan Dan Kerentanan Pangan Provinsi Bengkulu dapat digunakan sebagai indikator kinerja sehingga hendaknya hasil penyusunan Peta Ketahanan dan Kerentanan Pangan di Provinsi Bengkulu disusun dengan cepat, dan diselesaikan tepat waktu tanpa mengulur waktu sehingga pihak pemerintah cepat memberikan strategi untuk mencegah/memulihkan kerawanan Pangan Provinsi Bengkulu.

\section{DAFTAR PUSTAKA}

Badan Ketahanan Pangan Provinsi Bengkulu. 2015. Laporan Akuntabilitas Kinerja Instansi Pemerintah 2014.

Dewan Ketahanan Pangan dan World Food Programme. Peta Kerawanan Pangan Indonesia (FIA), 2005

Hanani. 2012. Kebijakan Nasional Pemantapan Ketahanan Pangan. Makalah pada Seminar Nasional Teknologi Pangan, Semarang

Ketersediaan Pangan.2012. http://www.bkp3.malangkab.go.id (Diakses tanggal 25 November 2015).

Nazir, M. 1999. Metode Penelitian. Ghalia Indonesia. Jakarta.

Rachman, HPS dan Ariani, M. 2002. Analisis Tingkat Ketahanan Pangan Rumah Tangga. Media Gizi dan Keluarga

Suhardjo, 1996. Perencanaan Pangan dan Gizi, Jakarta; Bumi Aksara.

Yudo Husodo. 2008. Kemandirian di Bidang Pangan, Kebutuhan Negara Kita. Makalah Kunci pada Seminar Nasional Teknologi Pangan, Semarang

90 | Gita Mulyasari, Kajian Ketahan Pangan dan Kerawanan Pangan ... 